$\stackrel{N / 2}{N}$

Global Journals Inc

s.

GLOBAL JOURNAL OF MANAGEMENT AND BUSINESS RESEARCH: A

ADMINISTRATION AND MANAGEMENT

Volume 20 Issue 3 Version 1.0 Year 2020

Type: Double Blind Peer Reviewed International Research Journal

\title{
Strategic Agility: Achieving Superior Organizational Performance through Strategic Foresight
}

By Arokodare, M. A. \& Asikhia, O. U.

Babcock University

Abstract- Firms globally encounter challenges of maintaining business superior performance over a long period. Most business organizations managers in today's modern age, find it difficult to constantly achieve targeted business performance due to poor strategic insight and agility to manage uncertainty business environment and globalization in the 21 st century. The majority of firms in the 21 st century have recorded a fast decline in financial and non- financial performance resulting from a poor understanding of strategic agility dimensions to tackle global business trends and environmental turbulence. Theoretically, the study was conducted to investigate the link between strategic agility and firm performance through strategic foresight as part of antecedent of strategic foresight. The Dynamic Capability and Entrepreneurship Innovation theories were the underpinning theories for the study. Thus a conceptual model was developed to depict the interaction between strategic agility and firm performance through strategic foresight. Majority of past literature shown that strategic agility and strategic foresight have significantly enhanced firm superior performance.

Keywords: dynamic capability, entrepreneurship innovation, firm performance, strategic agility and strategic foresight.

GJMBR-A Classification: JEL Code: M10

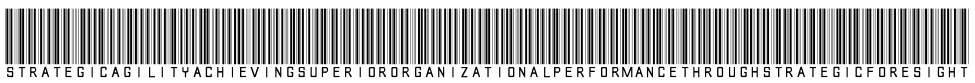

Strictly as per the compliance and regulations of:

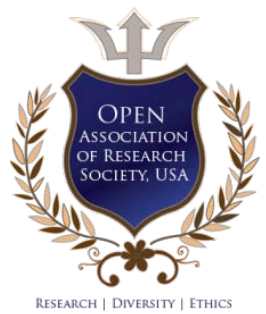

(C) 2020. Arokodare, M. A. \& Asikhia, O. U. This is a research/review paper, distributed under the terms of the Creative Commons Attribution-Noncommercial 3.0 Unported License http://creativecommons.org/licenses/by-nc/3.0/), permitting all non-commercial use, distribution, and reproduction in any medium, provided the original work is properly cited. 


\title{
Strategic Agility: Achieving Superior Organizational Performance through Strategic Foresight
}

\author{
Arokodare, M. A. ${ }^{\alpha}$ \& Asikhia, O. U. ${ }^{\sigma}$
}

Abstract- Firms globally encounter challenges of maintaining business superior performance over a long period. Most business organizations managers in today's modern age, find it difficult to constantly achieve targeted business performance due to poor strategic insight and agility to manage uncertainty business environment and globalization in the 21st century. The majority of firms in the 21st century have recorded a fast decline in financial and non- financial performance resulting from a poor understanding of strategic agility dimensions to tackle global business trends and environmental turbulence. Theoretically, the study was conducted to investigate the link between strategic agility and firm performance through strategic foresight as part of antecedent of strategic foresight. The Dynamic Capability and Entrepreneurship Innovation theories were the underpinning theories for the study. Thus a conceptual model was developed to depict the interaction between strategic agility and firm performance through strategic foresight. Majority of past literature shown that strategic agility and strategic foresight have significantly enhanced firm superior performance. This paper recommended that organizational managers should employ strategic agility conceptual measures with strategic foresight in their business thinking, activities, processes and directions to achieve superior performance.

Keywords: dynamic capability, entrepreneurship innovation, firm performance, strategic agility and strategic foresight.

\section{INTRODUCTION}

$\mathrm{O}$ rganizations around the globe are in a continuous dilemma of maintaining business performance. Most business organization managers around the world find it difficult to constantly achieve targeted business performance due to the dynamic nature, open market competition and globalization characterized with the 21st-century industry. Firms in different industries around the world have experienced unstable performance, seemingly uncertain on strategies to employ in reacting to flexible policies and unstable performance arising from challenges in the local and international business context.

Author a: Ph. D. Student, Department of Business Administration and Marketing, Babcock University, Illisan-Remo, Sagamu, Ogun State, Nigeria.e-mail: biodunarokodare@yahoo.com

Author $\sigma$ : Professor of Business Administration and Marketing, Department of Business Administration and Marketing, Babcock University, Illisan-Remo, Sagamu, Ogun State, Nigeria.
The decline in performance of firms, according to Zafari (2017) cut across developed, emerging and developing countries due to poor strategic agility and Inadequate response to microeconomic and macroeconomic factors challenges like performance industry environmental factors, task environment, natural and technological environments, social environments, economic and cultural environments, and political, law and security environments coupled with the management of marketing content and product marketing. In developing countries especially African countries, harsh economic and external conditions have placed pressure on firm performance among the African countries (Bredenhann, 2019). The challenges facing firms operating in Africa are diverse and numerous such as political interference, lack of transparency, regulatory uncertainty, policy instability, ongoing infrastructure deficit, uncertainty, delays in passing laws, energy policies and regulations into law are stifling growth, development and investment in several countries around Africa (PWC, 2018).

Nigeria inability to attract fresh investment in different sectors or expand existing ones has left the country in a precarious situation. The loss of investment in Nigeria has become the gain of other countries, including, Ghana, Gabon and Angola, which have become new frontiers for business consideration in Africa. Oyerinde, Olatunji and Adewale (2018) pointed out that most of firms in Nigeria have recorded unstable performance due to slow agility response to challenges of political interference, lack of transparency, regulatory uncertainty and policy instability, and poor infrastructural facilities. Furthermore, Oyerinde et al. (2018) emphasized that poor strategic agility to these challenges by firms in different industries has created unstable firm performance in Nigeria

In this modern day of 21 st-century where globalization, technology, innovation and diverse products are boundary less to any economy, organizations without strategic agility are bound to experience competitive disadvantage and continuous decline in performance. Rohrbeck and Kum (2018) asserted that strategic agility enhances firm's future preparedness and are powerful predictors for becoming an outperformer in the industry, for attaining superior profitability, and for gaining superior market 
capitalization growth. They further emphasized that organizations with strategic agility character gain strategic foresight in securing future superior performance and competitive advantage.

Strategic foresight involves multiple stakeholders and creates value through providing access to critical resources ahead of competition, preparing the organization for change, and permitting the organization to steer proactively towards a desired future in order to achieve prosperity (Baskarada, Shrimpton, Ng, Cox \& Saritas, 2016). The concept of strategic foresight addresses the problem of a constantly changing environment, derivation of competitive advantage, market position and firm superior performance (Albright, 2004; Rohrbeck, Battistella, \& Huizingh, 2015). It enhances the identification, observation and interpretation of corporate environmental changes and potential opportunities by determining possible implications as well as responses (Baskarada et al. 2016; Sardar, 2010). Generally having a long-term orientation, strategic foresight involves broadening the menu of policy options and taking into account future scenarios that might affect present decisions and enhance firm superior performance (Leigh, 2003; Baskarada et al., 2016).

Moreover, several studies have argued thatstrategic agilityhelpsin dealing with the challenges oforganizational performance (Kitonga, 2017; Nejatian, Zarei, Nejati\&Zanjirchi, 2018; Appelbaum, Calla, Desautels \& Hasan, 2017). However, Oyerinde et al. (2018) and Onigbinde (2014) had pointed out that majority of firms recorded continuous decline in performance due to poor strategic agility and reaction to environmental challenges surrounding firms in Nigeria. Various studies within and outside Nigeria context have investigated how strategic agility affect firm performance in different industries(Alhadid, 2016; Arbussa, Bikfalvi \& Marques, 2017; Hemmati, Feiz, Jalilvand \& Kholghi, 2016; Liang, Kuusisto \& Kuusisto, 2018; Nejatian, Zarei, Nejati \& Zanjirchi, 2018; Osisioma, Nzewi \& Mgbemena, 2016; Olbert, Prodoehl\& Worley, 2017; Oyedijo, 2012;Sadjak, 2015; Sampath, 2015; Somuyiwa, Adebayo \& Akanbi, 2011; Appelbaum, Calla, Desautels \& Hasan, 2017; Vecchiato, 2014 among others), but these past studies have not conceptualized strategic agility and firm performance as this study intend to measure both strategic agility and firm performance.

Relatively, most of these past studies reviewed have not established the combined link between strategic agility and firm performance dimensions in the manner in which this study have conceptualized strategic agility and firm performance. This serves as variable conceptual measurement gap that this study intends to establish. In this paper, the dimensions for strategic agility are: strategic insight, internal response orientation, external response orientation, human resources capability, information technology capability) and firm performance (market share, firm profitability, firm efficiency, competitive advantage, customer satisfaction and firm creativity). Hence this paper conducts a theoretical model on the model link between strategic agility and superior organizational performance dimensions through strategic foresight.

\section{Theoretical Foundations}

This paper adopted Dynamic Capabilities Theory and Entrepreneurship Innovation Theory as baseline theories for this study. These theories were selected to guide this study because their perspectives are tied to the focus of the study and the variables under investigation. The justification for these theories employed in this study is based on their theoretical explanation of the study variables.

Dynamic Capability Theory (DCT) is the capability of an organization to purposefully adapt an organization's resource base. Dynamic capabilities theory (DCT), which was developed by Teece, Pisano and Shuen (1997) was defined as "the firm's ability to integrate, build, and reconfigure internal and external competences to address rapidly changing environments" (p. 516) and it examines how firms address or bring about changes in their turbulent business environment through reconfiguration of their firm-specific competencies into new competencies (Teece, 2007).The concept of Dynamic Capabilities Theory (DCT)explained the mechanism that links resources and product markets to competitive advantage and firm survival. The DCT further explain how firms gain sustainable competitive advantage, survive in competitive and turbulence business environment in several ways.

The DCT frame work work on three fundamental presumptions. Firstly, the capacity to sense and shape opportunities. Secondly, to seize opportunities. Thirdly, to maintain competiveness through reconfiguring the enterprise's assets (Teece, 2007).Despite the popularity and insightful theoretical foundation, the DCT approach does not answer all questions of sustainable competitive advantage. Zahra, Sapienza and Davidsson (2006) argue that that there are some inconsistencies and ambiguities in the literature of DCT. Another criticism of the concept is that DCT are difficult to measure empirically. In the opinion of Ambrosini, Bowman and Collier (2009), to understand dynamic capabilities, the managerial perceptions of the need for change functions of their perceptions of their firms' external and internal environments need to be considered. Thus, it is possible for a manager to misperceive the need for change and as a result fail to apply appropriate DCT.

The DCT framework help scholars to understand the foundations of long-run enterprise success while helping managers delineate relevant strategic considerations and the priorities they must adopt to enhance enterprise performance and escape 
the zero profit tendency associated with operating in markets open to global competition(Teece, 2007). The framework integrates the strategy and innovation literature and highlights the most important capabilities that the management need in order to sustain superior long run business performance (Teece, 2007). Easter by-Smith, Lyles and Peteraf (2009) emphasized that DC are higher-level capabilities, which enable knowledge gathering, fast response, sharing, and continual updating of the operational processes, interaction with the environment and decision-making evaluations in order to achieve firm competitive advantages and performance. More recently, Esbach (2009) view DC as the capacity of an organization to purposefully create and agile and modify firm resource base so as gain competitive advantage.

The Entrepreneurship Innovation Theory (EIT) was propounded by Schumpeter (1934, 1942). The theory ascribed that entrepreneurship is about combining resources in new ways such as introduction of new products with better attractions, new methods of production, discovery of a new market(s), identification of new source (s) of supply of raw materials and alteration of existing market arrangements through innovation that brings about radical changes in the market. He regards innovation as a tool of an entrepreneur. The assumption of Entrepreneurship Innovation Theory includes the discovery of a new product, opening of a new market, reorganization of an industry and development of a new method of production.

Chepurenko (2015) critic entrepreneurship Innovation Theory that; Innovations are only one of many factors causing cyclical fluctuations in a capitalistic economy. Also it is difficult to differentiate their innovating activity from their ordinary business activity. Furthermore, Chepurenko (2015) asserted Entrepreneurship Innovation theory is criticized because it seems to be one-sided as it puts too much emphasis on innovative functions. It ignores risk taking function and Schumpeter's views are particularly applicable to developing countries where innovations need to be encouraged.

The entrepreneurship innovational activities have become a matter of routine these days and there is no need of special agent like innovator for carrying on such activities and thus Schumpeter has over glorified the place of innovator in his model (Small bone \& Welter, 2009).The entrepreneur is also viewed as the engine of growth' which sees the opportunity for introducing new products, new markets, new sources of supply, new forms of industrial organization or for the development of newly discovered resources so as to achieve firm competitive advantage and overall performance (Madsen, 2007).

\section{ili. Conceptual Review of Strategic Foresight and Strategic Agility}

\section{a) Strategic Foresight}

Strategic foresight (SF) is one of the dimensions of strategic sensitivity (Mavengere, 2013), serves as part of the antecedents of strategic agility, identifying, observing and interpreting factors that induce change, determining possible organization-specific implications and triggering appropriate organizational responses (Rohrbeck, Thom \& Arnold, 2015). It encompasses the appreciation, learning and anticipation of unveiling environmental trends (Inkinen \& Kaivo-oja, 2009) and focuses on the short-term and long term that are termed track changes and pattern recognition respectively (Mavengere, 2013).

Strategic foresight is regarded as a process that enhances an organisation's ability to understand the emerging risks and opportunities, drivers, motivations, resources, evolution, and causalities that are linked to alternative decisions, that form the space of possible, plausible, probable or preferred futures paths, so that the organisation can make better informed and prepared decisions on issues concerned with its overall strategic plans and means of achieving its long-term objectives (Kuosa, 2016). It is the analysis of the likely evolution of the business environment in order to promptly detect the opportunities and the threats brought about by the emerging trends and to deal with them properly. It is a set of practices that enable firms to attain superior performance and increase in future markets position (Rohrbeck\&Kum, 2018).

\section{b) Antecedents of Strategic Foresight}

Strategic foresight has two main aspects: understanding, and anticipation of the future (Chia, 2002). It is built on the assumptions that: multiple futures are possible (that is, that future developments are uncertain and unpredictable); change (drivers) can be identified and studied, and the future can be influenced (Bereznoy, 2017: 12). The interest in strategic foresight is based on the idea to establish a corporate system that warns about unpleasant surprises and identifies emerging opportunities - a skill that large companies have proven to have difficulties with (Day \&S choemaker, 2004).

According to Rohrbeck, Battistella and Huizingh (2015), the elements of strategic foresight are:

i. Technology Intelligence which deals with the identification, assessment and usage of weak signals and information about emerging technologies and technological discontinuities;

ii. Competitive Intelligence which deals with the assessment of competitors and the identification 
and assessment of products and services in development or already available in lead markets;

iii. Political Environment Foresight which deals with the identification, assessment and usage of information on legislation, the political environment and on shifts in the political landscape; and

iv. Consumer Foresight which deals with the identification, assessment and anticipation of consumer needs as well as lifestyle and sociocultural trend of that environment.

\section{c) Strategic Agility}

Strategic Agility (SA) is defined by TabeKhoshnood and Nematizadeh (2017) as a concept consisting of two components: responsiveness and knowledge management. They further interpret strategic agility as the ability of an organization to detect changes through the opportunities and threats existing in the business environment, and to give rapid response through the recombination of resources, processes and strategies. Extensive review of the SA literature shows that an agile organization can be successful in competitive environment through the abilities of responsiveness, competence, flexibility and speed so that it achieves competitive advantage in the market (Ganguly, Nilchiani\& Farr, 2009; Oyedijo, 2012). Doz and Kosonen (2008) considered SA to be a means by which organisations transform, reinvent themselves, adapt, and ultimately survive. They see SA as the capacity of a firm to continuously adjust and adapt its strategic direction in a core business in order to create value for the firm. Sampath (2015) considered SA to be about being adaptive to changes in the business context, spotting opportunities, threats and risks, and launching new strategic initiatives rapidly and repeatedly; while Teece, Peteraf and Leih (2016) referred to SA as "the capacity of an organization to efficiently and effectively redeploy and redirect its resources to value creating and value protecting (and capturing) higher-yield activities as internal and external circumstances warrant" (p. 8).

In this study, other strategic agility conceptualizations are: strategic insight, internal response orientation, external response orientation, human resource capability, and information technology capability.

\section{d) Strategic Insight}

Strategic insight (SI) is the second subconstruct of strategic sensitivity (SS) construct of SA (Mavengere, 2013). It is the tendency of an organization to focus on the present by drawing knowledge from complex strategic situations as they emerge and analyzing them for the organization to benefit from the situations as they unfold (Doz \& Kosonen, 2008). In the context of the organization, SI encompasses both the outside view, or external sensing and inside view, or internal awareness (Mavengere, 2013). Internal awareness through probing and experimenting, highlights the organisation's strength and weaknesses in the light of the environment and this may lead to a challenge of the firm's core business assumptions and help to define, refine, and sharpen them. External sensing on the other hand, enables the executives to see their organization from different perspectives when they distance themselves from their routine and they start modelling the organization and its relationship to its environment (Doz \& Kosonen, 2010).

\section{e) Internal Response Orientation}

Internal response orientation (IRO) is a subconstruct of strategic response (SR), a dimensional construct of SA. Strategic response is the ability of an organisation, working in collaboration with its customers and business partners, to quickly and seamlessly reconfigure its resources and processes to react or proactive in line with changes and/or developments in the business environment (Mavengere, 2013).

\section{f) External Response Orientation}

Enternal response orientation (ERO) has been defined as the ability to predict market occurrences and developments before competitors (Doz \& Kosonen, 2008). It implies being open to as much information, intelligence and innovations as possible by creating and maintaining relationships with a variety of different people and organisations (Doz \& Kosonen, 2008). Hence, firms need to be oriented towards the market to become aware of the need for change. Mavengere (2013) viewed external response orientation (ERO), a sub-construct of the SR dimension of SA, as the ability of an organization to re-act or pro-act to the business environment.

\section{g) Human Resource Capability}

Alhadid (2016) defined HRC as consistent with people's capability and flexibility to have crucial roles in an agile organization which faces a permanent change in the circumstances. Human resources capability is a measure of the ability and competence of the workforce to effectively and efficiently do their duties (Mavengere, 2013). Gary, Wood and Pillinger (2012) and Kafi (2014) claimed that HRC is a group of practices and policies that are needed to implement various activities. Through them, management carries out its function to the best of its capabilities. Human resources capability can also be described, according to Al-Hosani, Mohammed-Arbab and Azzam-Elmasri (2017), as managerial activity related to the identification of project's needs in terms of workforce and a response to these needs by providing the appropriate workforce within the numbers and qualifications that correspond to the project's needs, and using these resources in an efficient way to achieve productivity. 


\section{h) Information Technology Capability}

In his taxonomy of strategic agility, Mavengere

(2013) identified information technology capabilities (ITC) as one of the sub-constructs of the collective capabilities dimension of SA and he described this as the ability of the organization to successfully utilize its information infrastructure and resources to derive value in order to improve its performance. It was his opinion that an organization with the required information infrastructure and resources for its core functions will be able to carry out its functions effectively while possession of such capabilities are important for the organization to utilize its information resource and promote information management in a competitive business environment.

\section{Conceptual Review of Superior Organizational Performance}

\section{a) Firm Performance}

In this paper firm performance was conceptually define and measure with non-financial performance like market share, firm profitability, firm efficiency, competitive advantage, customer satisfaction, firm creativity. The concept of firm performance (FP) is fundamental to businesses as the key objective for business organisations is profit making (Olanipekun, Abioro, Akanni, Arulogun \& Rabiu, 2015). Syafarudin (2016) defined FPasthe outcome or accomplishment affected by the operations of the company in utilizing the resources owned. Jahanshahi, Rezaie, Nawaser, Ranjbar and Pitamber (2012) also described FP as a result of the actual outcome fashioned by a company which is measured and compared with the expected results. Musyoka (2016) portrayed FPas having improvement over time as a result of the shared values in the company.

\section{b) Market Share}

According to Cole (2016), Market Share (MS) is the rate of a market either in units or in revenue, accounted for by a specific entity. Market share is calculated on a national level, as well as on more regional and local levels, to determine specific MS. The most basic way of calculating MS is to take the total number of sales for a company and then divide that number by the total sales for the industry. Essentially, MS is the percentage of consumers that a company has captured from its specific, desired market within an industry (Cooper \& Nakanishi, 2014).

\section{c) Firm Profitability}

Gibson (2009) defined firm profitability (FPR) of a firm as its ability to generate earnings. Greuning and Bratanovic (2009) view profitability as the indicator of how a company's profit margins are associated with sales and average capital. It is often expressed with the help of the ratio between this result and sales (or production). Stefea (2012) stated that FPR is the ability of a lucrative activity to generate revenues higher than expenses involved. The indicators of FPR are well known as profitability ratio or accumulation margin. Brigham, Gapenski and Ehrhardt (2009) considered that FPR is the net result of various policies and managerial decisions, and the profitability rates represent the net operating result of the combined effects of liquidity, asset management and debt management. The FPR may therefore be defined as the ability of a given investment to earn a return from its use.

\section{d) Firm Efficiency}

Cummings and Weiss (2013) view firm efficiency (FE) as the success of the firm in minimizing costs, maximizing revenues, or maximizing profits, conditional on the existing technology. Assessing the efficiency of firms is a powerful means of evaluating performance of firms, and the performance of markets and whole economies. There are several types of efficiency: al locative and productive efficiency, technical efficiency, dynamic efficiency and social efficiency (Chen \&Waters, 2017). Productive efficiency occurs when a firm is combining resources in such a way as to produce a given output at the lowest possible average total cost. Technical efficiency relates to how much output can be obtained from a given input, such as a worker or a machine, or a specific combination of inputs. The simplest way to differentiate productive and technical efficiency is to think of productive efficiency in terms of cost minimisation by adjusting the mix of inputs, whereas technical efficiency is output maximisation from a given mix of inputs.

\section{e) Competitive Advantage}

Competitive advantage (CA) is simply the ability of an organisation to stay ahead of present or potential competition. It is the superior performance or performance edge of an organization in form of market leadership. According to Ardianus and Petrus (2016), $\mathrm{CA}$ is anything that can be done better by the firm when compared to the competitors. Christensen (2010) defined CA as whatever value a business provides that motivates its customers (or end users) to purchase its products or services rather than those of its competitors and that poses impediments to imitation by actual or potential direct competitors. Competitive advantage is regarded as part of the foundation for high level performance (Ismail, Rose, Abdullah, \&Uli, 2010). A firm's ability to improve the quality of its products, reduce the costs of its products, or enlarge market share or profit is known as CA (Grupe \& Rose, 2010).

\section{f) Customer Satisfaction}

Customer satisfaction (CS) refers to the psychological notion that encompasses the feeling of comfort and pleasure that emanates from obtaining what one hopes for and expects (Ganiyu, 2017). 
According to Kotler (2001), "satisfaction is the feeling of pleasure or disappointment resulting from comparing the performance (or outcome) of a product or service perceived quality in relation to the buyer's expectation" (p. 58). Potluri and Hawariat (2010) defined CS as a short-term emotional reaction to a specific service performance. Muriithi (2013) defined CS as the attitude resulting from what customers think should happen (expectations) interacting with what customers think did happen (performance perceptions).

\section{g) Firm Creativity}

Creativity can be defined at three different levels: the individual, the group or team and the organization (Shalley \& Gilson, 2004). Individual creativity requires creative thinking, skills and intrinsic task motivation (Amabile, 1997). In organisations, creativity is the process through which new ideas are generated and developed which then make innovation possible (Paulus \& Nijstad, 2003). Therefore, while individual creativity is concerned with idea generation, team and organizational creativity is concerned with both idea generation and the implementation of these ideas which could then lead to the creation of new goods and services, new processes or new procedures (Andriopoulos \& Lowe, 2000). This study is concerned with organizational (firm) creativity (FC) as explained above.

Gaspersz (2005) defined creativity as the production of new and useful ideas. Goncalo and Staw (2006) defined creativity as the mental process that allows people to think up new and useful ideas. Andersen and Kragh (2015) described creativity as a process that results in novelty which is accepted as useful, tenable, or satisfying by a significant group of others at some pointin time. Usually, innovation and creativity are considered to be closely related and, sometimes, the concepts are even used interchangeably (Amar \& Juneja, 2008). A widely agreed upon view distinguishes creativity from innovation in that creativity refers to production of ideas, whereas innovation refers to the successful implementation of ideas (McLean, 2005).

\section{Interaction Model Between Strategic Agility and Organizational Performance Dimensions Through StRATEGIC Foresight}

The conceptual model for this study shows the link between independent variable $(Y)$ and dependent variable. The dependent variable is firm performance conceptualized as; market share, firm profitability, firm efficiency, competitive advantage, customer satisfaction and firm creativity while the independent variable $(X)$ is strategic agility is also conceptualized as: strategic insight, internal response orientation, external response orientation, human resource capability and information technology capability with strategic foresight as part of antecedent concept of strategic agility. This indicate that strategic foresight also serves as part of conceptual measure for strategic agility. Based on the variable conceptual measurement gap identified in literature related to strategic agility and firm performance, this conceptual model depicted below in figure 1. 


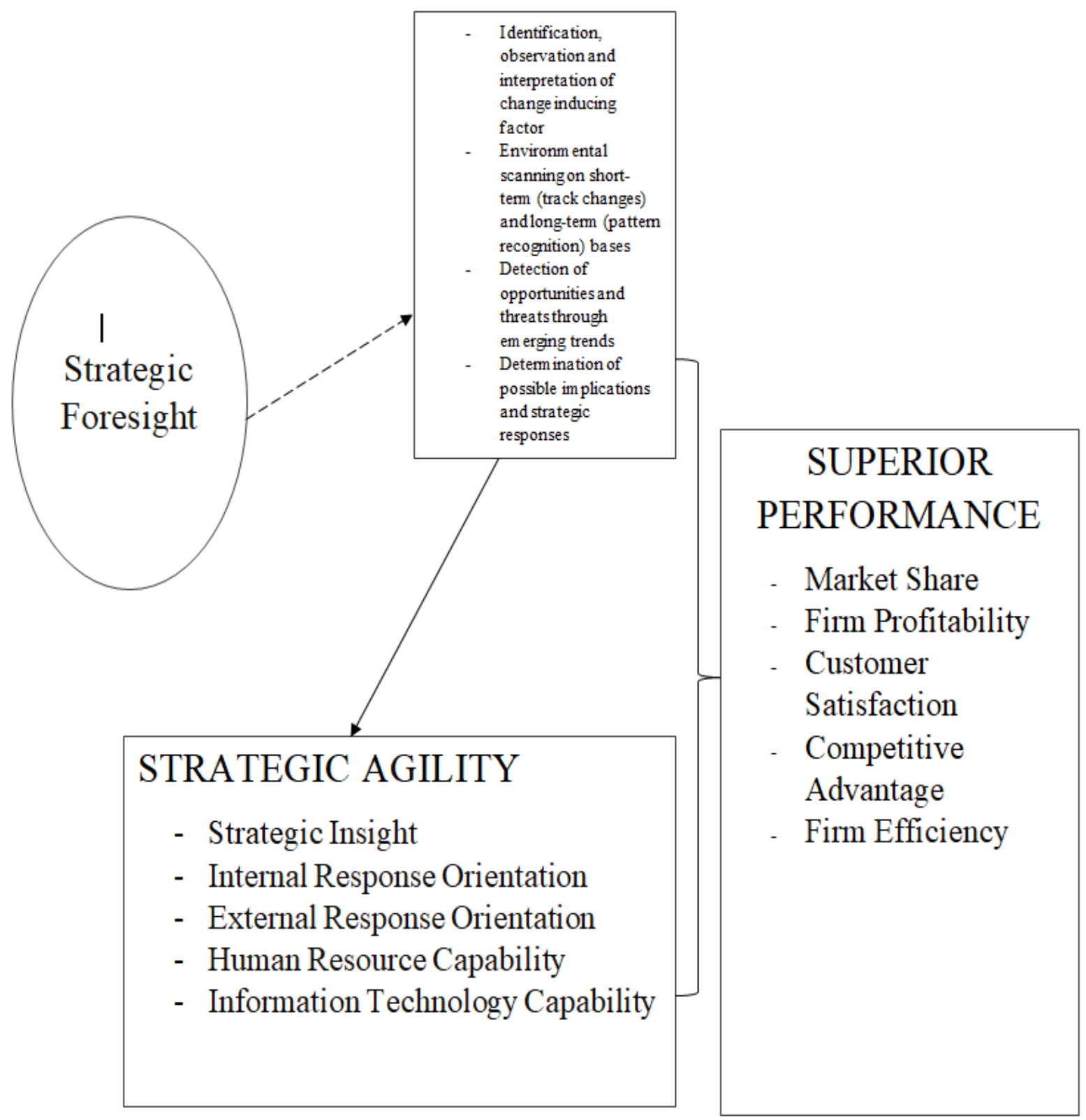

Figure 1: Researcher's Conceptual Model for Variables Measurement Gap; Source: Researcher's Literature Review (2019)

\section{Conclusion}

Strategic agility dimensions and strategic foresight are strategies or practices that may be complex to execute, apply and easily understood by organizations in this current $21^{\text {st }}$ century business trend where unstable environmental turbulence hindered firm performance. Literatures have shown that strategic foresight comprises of identification, observation and interpretation of change inducing factor, environmental scanning on short-term (track changes) and long-term (pattern recognition) bases, detection of opportunities and threats through emerging trends and determination of possible implications and strategic responses which augment the process of strategic agility thus enhance firm superior performance. Conceptually, organizational culture, organizational work force characteristics, organizational structure, building, deployment and redeployment of appropriate organizational capabilities can be viewed asserving antecedents of strategic foresight which enhance strategic agility and firm superior performance apart from other measures of strategic agility such as strategic insight, internal response orientation, external response orientation, human resource capability and information technology capability. Consequently, majority of past studies established that strategic agility and foresight have significantly enhanced firm superior performance across different industries. 


\section{Vil. ReCOMMENDATION}

Basically, organizational managers should endeavor to embrace strategic agility dimensions and strategic foresight in order to achieve superior performance such as market share, firm profitability, firm efficiency, competitive advantage, customer satisfaction and firm creativity. Hence, this study further recommended that organizational policy maker, owners and managers should employ both strategic agility and foresight in their business activities, processes, decisions and direction so as to achieve superior competitive advantage and overall performance. Further study should empirically investigate how strategic foresight moderates the relationship between strategic agility and superior firm performance in oil and gas industry and other key industries that determine economic activities, growth and development in Nigeria. Similarly, further study should also empirically examine how Nigeria higher institutions (Universities and Polytechnics) can employ strategic agility and foresight in enhancing global educational standard and superior performance.

\section{References Références Referencias}

1. Albright, K. S. (2004). Environmental scanning: Radar for success. Information Management Journal, 38(3), 38-45.

2. Alhadid, A. Y. (2016). The effect of organization agility on organization performance. International Review of Management and Business Research, 5(1), 273.

3. Al-Hosani, A. Mohammed-Arbab, A. \& AzzamElmasri, A. (2017). Does information technology affect improvement of human resources directorate's performance in a selected organization in the Kingdom of Bahrain? International Business and Management, 15(1), 8-14.

4. Amabile, T. M. (1997). Motivating creativity in organizations: On doing what you love and loving what you do. California Management Review, 40(1), 39-58.

5. Amar, A. D., \& Juneja, J. A. (2008). A descriptive model of innovation and creativity in organizations: A synthesis of research and practice. Knowledge Management Research \& Practice, 6(4), 298-311.

6. Ambrosini, V., Bowman, C., \& Collier, N. (2009). Dynamic capabilities: An exploration of how firms renew their resource base. British Journal of Management, 20(S1), S9-S24.

7. Andersen, P. H., \& Kragh, H. (2015). Exploring boundary-spanning practices among creativity managers. Management Decision, 53(4), 786-808.

8. Andriopoulos, C., \& Lowe, A. (2000). Enhancing organisational creativity: The process of perpetual challenging. Management Decision, 38(10), 734742.
9. Appelbaum, S. H., Calla, R., Desautels, D., \& Hasan, L. (2017). The challenges of organizational agility (part 1). Industrial and Commercial Training, 49(1), 6-14.

10. Arbussa, A., Bikfalvi, A., \& Marquès, P. (2017). Strategic agility-driven business model renewal: The case of an SME. Management Decision, 55(2), 271293.

11. Ardianus, L. P., \& Petrus, M. (2016). The utilization of resource-based view theory on minimarket retail: Its implication toward strategy and competitive advantage. The 1st International Conference on Economics, Education, Business, and Accounting, 3(7), 1-23.

12. Baskarada, S., Shrimpton, D., Ng, S., Cox, D., \& Saritas, O. (2016). Learning through foresight. Foresight, 18(4).

13. Bereznoy, A. (2017). Corporate foresight in multinational business strategies. Форсайm, 11(1), (eng).

14. Bredenhann, C. (2019). African oil \& gas industry. PwC Africa oil and gas advisory leader report.

15. Brigham, E. F., Gapenski, W. A., \& Ehrhardt, M. C. (2009). Financial Management: Theory and Practice,11th Edition, South-Western College Publishers, New York

16. Chen, J., \& Waters, G. (2017). Firm efficiency, advertising and profitability: Theory and evidence. The Quarterly Review of Economics and Finance, 63, 240-248.

17. Chepurenko A. (2015) Entrepreneurship theory: New challenges and future prospects. ForesightRussia, 9(2), 44-57.

18. Chia, R. (2002). Essay: Time, duration and simultaneity: Rethinking process and change in organizational analysis. Organization Studies, 23(6), 863-868.

19. Christensen, H. (2010). Defining customer value as the driver of competitive advantage. Strategy \& Leadership, 38(5), 20-25.

20. Cole, R. A. (2016). Do banks or VCs spur small firm growth? Journal of International Financial Markets, Institutions and Money, 41, 60-72.

21. Cooper, Y., \& Nakanishi, D. (2014).Implementing strategic missions: Effective strategic, structural and tactical choices. Journal of Management Studies, $31(4), 481-505$.

22. Cummins, J. D., \& Weiss, M. A. (2013).Analyzing firm performance in the insurance industry using frontier efficiency and productivity methods. In Handbook of Insurance (pp. 795-861). Springer, New York, NY.

23. Day, G. S., \& Schoemaker, P. (2004). Peripheral vision: Sensing and acting on weak signals. Long Range Planning, 2(37), 117-121. 
24. Doz, Y. L., \& Kosonen, M. (2008). Fast strategy: How strategic agility will help you stay ahead of the game. Pearson Education.

25. Doz, Y. L., \& Kosonen, M. (2010). Embedding strategic agility: A leadership agenda for accelerating business model renewal. Long Range Planning, 43(2-3), 370-382.

26. Easterby-Smith, M., Lyles, M. A., \& Peteraf, M. A. (2009). Dynamic capabilities: Current debates and future directions. British Journal of Management, 20, S1-S8.

27. Esbach, J. (2009). Relevance of engineering entrepreneurship: A study at Cape Peninsula University of Technology. Journal of Asia Entrepreneurship and Sustainability 5(3), 108.

28. Ganguly, A., Nilchiani, R., \& Farr, J. V. (2009). Evaluating agility in corporate enterprises. International Journal of Production Economics, 118(2), 410-423.

29. Ganiyu, R. A. (2017). Customer satisfaction and loyalty: A study of interrelationships and effects in Nigerian domestic airline industry. Oradea Journal of Business and Economics, 2(1), 7-20.

30. Gaspersz, J. (2005). Compete with creativity. Essay presented at the innovation lecture "Compete with creativity" of the Dutch Ministry of Economic Affairs.

31. Gary, M. S., Wood, R. E., \& Pillinger, T. (2012).Enhancing mental models, analogical transfer, and performance in strategic decision making. Strategic Management Journal, 33(11), 1229-1246.

32. Gibson, C. H. (2009). Financial Reporting and Analysis, Using Financial Accounting Information. (11th Ed.). USA: Cengage Learning.

33. Goncalo, J. A., \& Staw, B. M. (2006). Individualismcollectivism and group creativity. Organizational Behavior and Human Decision Processes, 100(1), 96-109.

34. Greuning, H. \& Bratanovic, S. B. (2009). Analyzing banking risk: A framework for assessing corporate governance and risk management, (3rd Edition) Washington: The World Bank.

35. Grupe, C., \& Rose, A. (2010).China, India, and the socioeconomic determinants of their competitiveness. Economics Research International.

36. Hemmati, M., Feiz, D., Jalilvand, M. R., \& Kholghi, I. (2016).Development of fuzzy two-stage DEA model for competitive advantage based on RBV and strategic agility as a dynamic capability. Journal of Modelling in Management, 11(1), 288-308.

37. Inkinen, S., \& K aivo-Oja, J. (2009). Understanding innovation dynamics. Aspects of Creative Processes, Foresight Strategies, Innovation Media and Innovation Ecosystems, 9.

38. Ismail, A. I., Rose, R. C., Abdullah, H., \& Uli, J. (2010). The relationship between organisational competitive advantage and performance moderated by the age and size of firms. Asian Academy of Management Journal, 15(2), 157-173.

39. Jahanshahi, A. A., Rezaei, M., Nawaser, K., Ranjbar, V., \& Pitamber, B. K. (2012). Analyzing the effects of electronic commerce on organizational performance: Evidence from small and medium enterprises. African Journal of Business Management, 6(22), 6486-6496.

40. Kitonga, D. M. (2017). Strategic leadership practices and organizational performance in not-for-profit organizations in Nairobi County in Kenya (Doctoral dissertation, COHRED, Jomo Kenyatta University of Agriculture and Technology).

41. Kuosa, T. (2016). The evolution of strategic foresight: Navigating public policy making. Routledge.

42. Leigh, A. (2003). Thinking ahead: Strategic foresight and government. Australian Journal of Public Administration, 62(2), 3-10.

43. Liang, L., Kuusisto, A., \& Kuusisto, J. (2018).Building strategic agility through user-driven innovation: The case of the Finnish public service sector. Theoretical Issues in Ergonomics Science, 19(1), 74-100.

44. Madsen, E. L. (2007). The significance of sustained entrepreneurial orientation on performance of firms: A longitudinal analysis. Entrepreneurship \& Regional Development, 19(2), 185- 204.

45. Mavengere, N. B. (2013). Information technology role in supply chain's strategic agility. International Journal of Agile Systems and Management,6(1),7-

46. McLean, L. D. (2005). Organizational culture's influence on creativity and innovation: A review of. the literature and implications for human resource development. Advances in Developing Human Resources, 7(2), 226-246.

47. Muriithi, M. K. (2013). The determinants of healthseeking behavior in a Nairobi slum, Kenya. European Scientific Journal, ESJ, 9(8).

48. Musyoka, S. M. (2016). Factors that influence organizational performance in the hospitality industry: A case study of Sankara Nairobi. A MBA Project Report. Chandaria School of Business.

49. Nejatian, M., Zarei, M. H., Nejati, M., \& Zanjirchi, S. M. (2018). A hybrid approach to achieve organizational agility: An empirical study of a food company. Benchmarking: An International Journal, 25(1), 201-234.

50. Olanipekun, W. D., Abioro, M. A., Akanni, L. F., Arulogun, O. O., \& Rabiu, R. O. (2015). Impact of strategic management on competitive advantage and organisational performance- Evidence from Nigerian Bottling Company. Journal of Policy and Development Studies, 9(2), 185-198.

51. Olbert, S., Prodoehl, H. G., \& Worley, C.G. (2017). Agilitätals Wettbewerbsvortei I- Der Agile Performer Index. Retrieved from 
https://www.goetzpartners.com/uploads/tx_gp/2017 goetzpartners_Agile_Perfor mer_Index.pdf.

52. Onigbinde, I. O. (2014). Evaluation of petroleum products marketing in a globalizing economy: a conceptual evidence from Nigeria. British Journal of Marketing Studies 2(2), 71-81.

53. Osisioma, H., Nzewi, H., \& Mgbemena, I. (2016). Dynamic capabilities and performance of selected commercial banks in Awka, Anambra State, Nigeria. European Journal of Business and Social Sciences, 4(10), 98-110.

54. Oyedijo, A. (2012). Strategic agility and competitive performance in the Nigerian telecommunication industry: An empirical investigation. American International Journal of Contemporary Research, 2(3), 227-237.

55. Paulus, P. B., \& Nijstad, B. A. (Eds.). (2003). Group creativity: Innovation through collaboration. Oxford University Press.

56. Potluri, M. R., \& Hawariat, H. W. (2010). Assessment of after-sales service behaviors of Ethiopia telecom customers. African Journal of Economic and Management Studies, 1(1), 75-90.

57. PWC (2018). Review of the Nigeria oil andgas industry.

58. Rohrbeck, R., Battistella, C., \& Huizingh, E. (2015). Corporate foresight: An emerging field with a rich tradition. Technological Forecasting and Social Change, 101, 1-9.

59. Rohrbeck, R., \& Kum, M. E. (2018). Corporate foresight and its impact on firm performance: A longitudinal analysis. Technological Forecasting and Social Change, 129, 105-116.

60. Rohrbeck, R., Thom, N., \& Arnold, H. (2015). IT tools for foresight: The integrated insight and response system of Deutsche Telekom Innovation Laboratories. Technological Forecasting and Social Change, 97, 115-126.

61. Sajdak, M. (2015). Compilation of operational and strategic agility for ensuring the highest efficiency of company operations. Economics and Management, 7(2), 20-25.

62. Sampath, J. M. (2015). Exploring the significance of strategic agility in building sustainable competitive advantage for retail banks in India. Working Paper Series No.ST-16-01.SVKM's Narsee Monjee Institute of Management Studies, School of Business Management, deemed University.

63. Sardar, Z. (2010). Welcome to post-normal times. Futures, 42(5), 435-444.

64. Schumpeter, J. A. (1934). The Theory of Economic Development. Harvard University Press, Cambridge, MA.

65. Schumpeter, J.A. (1942). Creative destruction, capitalism, socialism and democracy, 825.
66. Shalley, C. E., \& Gilson, L. L. (2004). What leaders need to know: A review of social and contextual factors that can foster or hinder creativity. The Leadership Quarterly, 15(1), 33-53.

67. Smallbone D., \& Welter F. (2009) Entrepreneurship and small business development in post-socialist economies. London: Routledge.

68. Somuyiwa, A. O., Adebayo, I. T., \& Akanbi, T. A. (2011). Supply chain performance: An agile supply chain driven by information system (IS) capabilities. British Journal of Arts and Social Sciences, 1(2), 125-135.

69. Stefea, P. (2012). Cost control: A tool for cost management. Annals of Eftimie Murgu University Resita, Fascicle II, Economic Studies.

70. Syafarudin, A. (2016). Strategy of leadership and innovation in improving company performance against competitive advantage: A case study of PT. Pegadaian (Ltd) Indonesia. International Journal of Economics, Commerce and Management, 4(6), 471-482.

71. Tabe-Khoshnood, N. \& Nematizadeh, S. (2017). Strategic agility and its impact on the competitive capabilities in Iranian private banks. International Journal of Business and Management, 12(2), 220229.

72. Teece, D. J. (2007). Explicating dynamic capabilities: the nature and micro-foundations of (sustainable) enterprise performance. Strategic Management Journal, 28(13), 1319-1350.

73. Teece, D., Peteraf, M., \& Leih, S. (2016). Dynamic capabilities and organizational agility: Risk, uncertainty, and strategy in the innovation economy. California Management Review, 58(4), 1335.

74. Teece, D. J., Pisano, G., \& Shuen, A. (1997). Dynamic capabilities and strategic management. Strategic Management Journal, 18(7), 509-533.

75. Vecchiato, R. (2014). Creating value through foresight: First mover advantages and strategic agility. Technological Forecasting and Social Change, 101, 25-36.

76. Welter, F., \& Small bone D. (2011) Institutional perspectives on entrepreneurial behavior in challenging environments. Journal of Small Business Management, 49(1), 107-125.

77. Zafari, H. (2017). Marketing strategies to enhance profitability among international oil and gas service companies. Walden Dissertations and Doctoral Studies.

78. Zahra, S. A., Sapienza, H. J., \& Davidsson, P. (2006). Entrepreneurship and dynamic capabilities: A review, model and research agenda. Journal of Management Studies, 43(4), 917-955. 